\title{
Quantitative Phenetics and Taxonomy of Some Phlebotomine Taxa
}

\author{
JP Dujardin/ ${ }^{+}$, F Le Pont*, E Martinez**
}

UMR IRD-CNRS 9926, IRD Montpellier, Av. Agropolis, 911, Montpellier, France *ORSTOM La Paz, Casilla Postal 9214, La Paz, Bolivia **Instituto Boliviano de Biologia de Altura, Calle Claudio Sanjinez, La Paz, Bolivia

Elucidating the evolution of Phlebotominae is important not only to revise their taxonomy, but also to help understand the origin of the genus Leishmania and its relationship with humans. Our study is a phenetic portrayal of this history based on the genetic relationships among some New Word and Old Word taxa. We used both multilocus enzyme electrophoresis and morphometry on 24 male specimens of the Old Word genus Phlebotomus (with three of its subgenera: Phlebotomus, Spelaeophlebotomus and Australophlebotomus), and on 67 male specimens of the three New World genera, Warileya, Brumptomyia and Lutzomyia, (with three subgenera of Lutzomyia: Lutzomyia, Oligodontomyia and Psychodopygus). Phenetic trees derived from both techniques were similar, but disclosed relationships that disagree with the present classification of sand flies. The need for a true evolutionary approach is stressed.

Key words: Old World New World sand flies - multilocus enzyme electrophoresis - morphometrics

The oldest known species of Phlebotominae, Phlebotomites longifilis and P. brevifilis, two fossil records described from Lebanon, lived about 120 millions years ago (MYA) (Lewis 1982). The evolution of Phlebotominae since that time was probably driven by major tectonic events and related climatic changes that affected Pangaea. Phlebotominae are bloodsucking insects of temperate and tropical regions showing significant differences in ecological adaptations, endemism, relictuality and species richness. They include important vectors of Leishmania spp., Bartonella sp. and Phleboviruses.

The systematics of this subfamily, especially at the supraspecific level, has always been controversial (Lewis \& Dice 1982, Lane 1986). In the last two decades, a conservative approach based on practical criteria (Lewis et al. 1977) led to the present subdivision of the Phlebotominae into six genera: three Old World (OW) genera: Chinius (1 species), Phlebotomus (10 subgenera) and Sergentomyia (7 subgenera), and three New World (NW) genera: Brumptomyia (22 species), Warileya (6 species) and Lutzomyia (26 subgenera) (Lane 1993, Young \& Duncan 1994). This "stable" clas-

\footnotetext{
${ }^{+}$Corresponding author. Present address: IRD (ORSTOM) La Paz, Casilla Postal 9214, La Paz, Bolivia. Fax: +591-2243782 E-mail: dujardin@ mail.megalink.com. Received 26 October 1998 Accepted 10 June 1999
}

sification (Lewis et al. 1977) has been generally accepted, though it was considered as premature by some experts of the NW sand fly fauna, and different conceptions have been applied (Forattini 1973, Ready et al. 1980).

Recent attempts to bring evolutionary insight into this classification were those of two independent doctoral theses (Rispail 1990, Galati 1992). They used Hennigian methodology (Hennig 1972) based on 100 (Galati 1992) and 28 (Rispail 1990) adult morphological attributes. According to these studies, the NW genus Warileya (Rispail 1990, Galati 1992) and the OW Spelaeophlebotomus and Australophlebotomus (Rispail 1990) (both Phlebotomus subgenera) appeared to have older, more ancient origins than suggested by the present taxonomic classification (Rispail \& Leger 1998a). Both studies disagreed, however, on the evolutionary status of the NW genus Brumptomyia that is close either to Lutzomyia (Rispail 1990) or to Phlebotomus (Galati 1992), as well as that of the OW genus Sergentomyia (not included in our material), clustered with Spelaeophlebotomus (Rispail 1990) or with Lutzomyia (Galati 1992, 1995).

In the absence of available or relevant outgroup for Phlebotominae, we used a phenetic approach based on dissimilarity indexes, called here quantitative phenetics. By this appellation, we mean a non-phylogenetic approach intended to generate hypotheses about evolutionary history, and based on quantitative characters. It may be regarded as a heuristic device subject to capture some evolutionary trends among not too closely related organisms, where higher probability exists of agreement between phylogenetic and genetic divergences 
(Chavez et al. 1999). We applied it here to the males of some species of sand flies belonging to widely different genera. Quantitative characters are needed because they are more suited to estimate genetic differences than morphological attributes. To increase their likeliness of producing relevant information about evolutionary history, they must be submitted to appropriate analyses. An UPGMA tree was derived from genetic distances for isoenzyme electrophoresis (Nei 1987, Solé-Cava et al. 1994). A canonical variate analysis (multivariate discriminant analysis) was applied to metric data (Pimentel 1992, Sorensen \& Foottit 1992). Both statistical techniques have proved informative to outline evolutionary trends in other organisms (Simon 1992, Dujardin et al. 1999).

\section{MATERIALS AND METHODS}

Isoenzyme electrophoresis and morphometry were applied to the same adult males of the following nine species (Table I): Warileya fourgassiensis Le Pont \& Desjeux 1984, W. rotundipennis Fairchild \& Hertig 1951, Phlebotomus (Spelaeophlebotomus) gigas Parrot \& Schwetz 1937, P. (Australophlebotomus) notteghemae Leger \& Pesson 1993, P. papatasi Scopoli 1786, Lutzomyia (Lutzomyia) longipalpis (Lutz \& Neiva, 1912), L. (Psychodopygus) geniculata (Mangabeira 1941), Brumptomyia pintoi (Lima 1932), and Lutzomyia (Oligodontomyia) toroensis Le Pont, TorresEspejo \& Dujardin 1996 (Table I). The classification adopted here is from Young and Duncan (1994), who consider Psychodopygus as a Lutzomyia subgenus, but we grouped $L$. toroensis with two related species ( $L$. isopsi and $L$. oligodonta ) in the recently created Lutzomyia subgenus Oligodontomyia (Galati 1995).

Twelve enzyme systems (ALDH, AP, HK, GPD, GPI, IDH, ME, MDH, PEP, PGM, XDH and XO) were run on cellulose acetate according to Richardson et al. (1986) and Dujardin et al. (1996). For genetic relatedness analysis, a phenetic approach was preferred to a cladistic one because our material did not include an outgroup for Phlebotominae (see however comments of Fig. 1). As an immediate measure of genetic divergence, we computed the Jaccard's distances (Jackson et al. 1989) which do not depend on gene frequencies or on locus counting (Table III, below diagonal). From these distances, an UPGMA tree was constructed.

Using a camera lucida, we measured eight characters using features of the head (AIII, third antennal segment; EP, epipharynx; P5, fifth palpomere); the wing (WL, wing length, WW, wing width) and the genitalia (GF, genital filaments; GP, genital pump; LL, lateral lobe). Size-free variables could not be derived from our (log-transformed) data because of lack of highly significant correlation between the first pooled within-group principal component and some variables (Dos Reis et al. 1990). Thus, discriminant analysis included size and shape variation. The derived Mahalanobis distances (Mahalanobis 1936) (Table III, above diagonal) were also submitted to the same UPGMA tree-making method as for distances derived from electrophoretic data (Fig. 1, right side).

The correlation between Jaccard and Mahalanobis distances was explored by the Mantel test (10,000 runs), and illustrated by the exponential relationship between both distances.

TABLE I

Origins of male insects and dates of capture

Genus Phlebotomus $(\mathrm{OW}, \mathrm{n}=24)$

$P$. (P.) papatasi $(\mathrm{n}=10)$

P. (S.) gigas $(\mathrm{n}=4)$

$P$. (A.) notteghemae $(\mathrm{n}=10)$

Genus Warileya $(\mathrm{NW}, \mathrm{n}=20)$

W. fourgassiensis $(\mathrm{n}=10)$

$W$. rotundipennis $(\mathrm{n}=10)$

Genus Lutzomyia $(\mathrm{NW}, \mathrm{n}=40)$

L. (L.) longipalpis $(\mathrm{n}=10)$

L. (O.) toroensis $(\mathrm{n}=10)$

L. (P.) geniculata $(\mathrm{n}=20)$

Genus Brumptomyia (NW, $\mathrm{n}=7$ )

B. pintoi $(\mathrm{n}=7)$
Laboratory rearing, Montpellier (France), 1996

Meya-N'Zouari caves (République du Congo), 1996

Touaourou caves (Nouvelle Calédonie), 1997

Fourgassié caves (Guyane Française), 1985

Suapi (Bolivia), 1995

Santa Barbara, North Yungas (Bolivia), 1996

Toro Toro cave, Potosi (Bolivia), 1995

Forest, Carrasco, North Yungas (Bolivia), 1997

Forest, Carrasco, North Yungas (Bolivia), 1997

Fresh material, used for isoenzyme electrophoresis and morphometry, was collected by light traps by one of us (FLP) in the Republic of Congo, New Caledonia and Bolivia between 1995 and 1997. P. papatasi originated from the insectary of the Faculté de Médecine, Université de Montpellier (Prof. JP Dedet). W. fourgassiensis were mounted specimens examined by morphometry only. OW: Old World; NW: New World. 


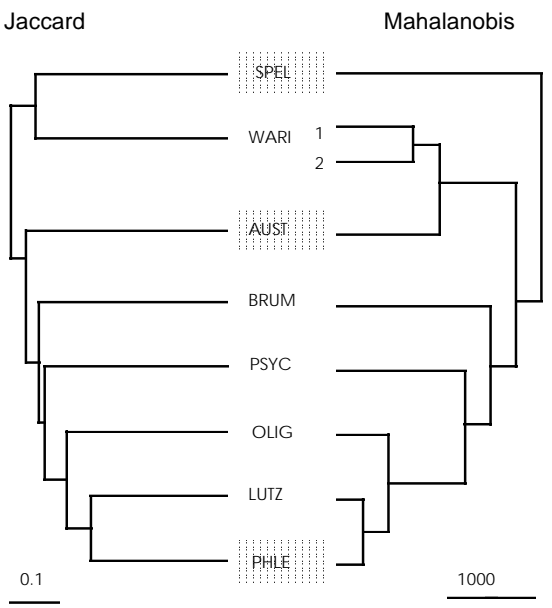

Fig. 1: topology of phenetic trees derived from either isoenzymes (left side) or metric data (right side). Shaded zones refer to Old World taxa. WARI: Warileya; 1: Warileya fourgassiensis (not examined by isoenzymes); 2: W. rotundipennis; AUST: Australophlebotomus; SPEL: Spelaeophlebotomus; BRUM: Brumptomyia; PSYC: Psychodopygus; OLIG: Oligodontomyia; PHLE: Phlebotomus; LUTZ: Lutzomyia. Although the two Warileya species showed striking differences in size, they were clustered together in the metric tree, indicating poor size-effect in the disclosed relationships. Using Warileya as a tentative outgroup, Hennigian methodology on isoenzymes produced a similar tree (results not shown). Presentation and scaling of the trees were obtained by TREE VIEW 1.5.2 (Copyright (C) Roderick DM Page, 1998 - r.page@bio.gla.ac.uk) on tree files generated by the PHYLIP 3.4 package.

\section{RESULTS}

Isoenzyme analysis - Each enzyme produced bands for each specimen. A total of 95 different electrophoretic band positions was recorded. In the total sample covering both $\mathrm{OW}$ and NW species, 37 alleles were found unique to one species, i.e. some species had one or more alleles not shared with other species. Notably, the NW genus Lutzomyia showed no unique allele. The maximum number of shared alleles between two species was found between a NW (L. longipalpis) and an OW ( $P$. papatasi) species, while the minimum number of shared alleles was found between either OW (Spelaeophlebotomus with Australophlebotomus) or NW representatives (see Warileya with either Psychodopygus or Oligodontomyia) (Table II, top). Subdividing the total sample into OW on one hand, and NW on the other hand, unique alleles were found more abundant in the former region $(74 \%$ versus $56 \%$ ), although it was represented by one genus only (Phlebotomus). Conversely, the proportion of alleles each region shared among its own taxa was lower in the OW $(16 / 61,26 \%)$ than among the four NW taxa belonging to three different genera $(34 / 77,44 \%)$. Both regions shared a total of 43 alleles (45\%, i.e. 43/95) (Table II, bottom).

Metric analysis - Although data were log-transformed before multivariate analysis, only three $(37 \%)$ characters (EP, WW, LL) had a distribution

TABLE II

Allelic composition of the total sample subdivided by taxa (top) or regions (bottom)

\begin{tabular}{|c|c|c|c|c|c|c|c|c|}
\hline Taxa & AUST & SPEL & PHLE & LUTZ & PSYC & OLIG & BRUM & WARI \\
\hline Total alleles & 16 & 21 & 29 & 28 & 28 & 23 & 29 & 24 \\
\hline Unique alleles & 2 & 5 & 4 & 0 & 6 & 4 & 8 & 8 \\
\hline Shared alleles & AUST & SPEL & PHLE & LUTZ & PSYC & OLIG & BRUM & WARI \\
\hline AUST & I & & & & & & & \\
\hline SPEL & 2 & I & & & & & & \\
\hline PHLE & 6 & 4 & l & & & & & \\
\hline LUTZ & 7 & 4 & 17 & I & & & & \\
\hline PSYC & 7 & 3 & 8 & 15 & l & & & \\
\hline OLIG & 6 & 4 & 10 & 14 & 10 & I & & \\
\hline BRUM & 3 & 6 & 11 & 14 & 8 & 8 & l & \\
\hline WARI & 5 & 8 & 6 & 4 & 2 & 2 & 6 & l \\
\hline \multicolumn{3}{|l|}{ Regions } & \multicolumn{3}{|c|}{ Old World } & \multicolumn{3}{|c|}{ New World } \\
\hline \multirow{2}{*}{\multicolumn{3}{|c|}{$\begin{array}{l}\text { Total alleles } \\
\text { Unique alleles }\end{array}$}} & \multicolumn{3}{|l|}{61} & \multicolumn{3}{|l|}{77} \\
\hline & & & \multicolumn{3}{|l|}{45} & \multicolumn{3}{|l|}{43} \\
\hline \multicolumn{3}{|c|}{ Shared alleles between species } & \multicolumn{3}{|c|}{ Old World } & \multicolumn{3}{|c|}{ New World } \\
\hline \multicolumn{3}{|c|}{ Old World } & \multicolumn{3}{|c|}{$16(26 \%)$} & \multicolumn{3}{|c|}{$43(45 \%)$} \\
\hline \multicolumn{3}{|l|}{ New World } & \multicolumn{3}{|c|}{$43(45 \%)$} & \multicolumn{3}{|c|}{$34(44 \%)$} \\
\hline
\end{tabular}

"Unique alleles" are alleles found in one species only ("unshared" alleles), either considering the total sample (top) or each region separately (bottom). Region refers to either Old World, with three taxa, or New World, with five taxa (see Materials and Methods). "Shared alleles" are alleles found in common between two species in the total sample (top), in each region separately (bottom) or between two regions (bottom). The three first taxa are Old World species AUST: Australophlebotomus; SPEL: Spelaeophlebotomus; PHLE: Phlebotomus. New World species are LUTZ: Lutzomyia; PSYC: Psychodopygus; OLIG: Oligodontomyia; BRUM: Brumptomyia; WARI: Warileya (W. rotundipennis). 
TABLE III

Jaccard (below diagonal) and Mahalanobis (above diagonal) distances

\begin{tabular}{lcccccccc}
\hline & AUST & SPEL & PHLE & LUTZ & PSYC & OLIG & BRUM & WARI \\
AUST & & 2330 & 669 & 809 & 1214 & 944 & 1397 & 293 \\
SPEL & 0.94 & & 949 & 944 & 1280 & 867 & 486 & 1693 \\
PHLE & 0.85 & 0.88 & & 58 & 350 & 148 & 237 & 764 \\
LUTZ & 0.81 & 0.89 & 0.57 & & 388 & 61 & 237 & 787 \\
PSYC & 0.81 & 0.94 & 0.85 & 0.66 & & 391 & 477 & 998 \\
OLIG & 0.82 & 0.86 & 0.73 & 0.62 & 0.78 & & 231 & 777 \\
BRUM & 0.93 & 0.87 & 0.78 & 0.69 & 0.85 & 0.83 & & 1182 \\
WARI & 0.86 & 0.80 & 0.88 & 0.92 & 0.96 & 0.96 & 0.80 & \\
\hline
\end{tabular}

Below diagonal are the Jaccard's distances $(\mathrm{Dj})$ derived from electrophoretic data. Above diagonal are the Mahalanobis distances (Dm) computed from discriminant analysis on (log-transformed) measurements of head, wing and genitalia characters. The three first taxa are Old World species AUST: Australophlebotomus; SPEL: Spelaeophlebotomus; PHLE: Phlebotomus. New World species are LUTZ: Lutzomyia; PSYC: Psychodopygus; OLIG: Oligodontomyia; BRUM: Brumptomyia; WARI: Warileya (W. rotundipennis).

that conformed with normality, and only two were compatible with homoscedasticity (equal variances among groups) (detailed results not shown). Normality and homoscedasticity are the current assumptions of discriminant analysis (also called canonical variate analysis), however departure from these assumptions are known to have little influence on analysis (Pimentel 1992). Discriminant analysis was highly significant $(\mathrm{P}<0.000$ after Wilk's test) (Wilks 1932).

Correspondance between analyses - Both trees produced the same topology except for the closer clustering of Warileya and Australophlebotomus after morphometric analysis, or the closer clustering of Warileya and Spelaeophlebotomus after isoenzyme analysis. These three genera were the most external ones in both trees (see Fig. 1). Grouping them into one OTU (organizational taxonomic unit), morphometrics and isoenzyme data produced the same topology. For at least six OTUs to produce by chance an identical topology after different techniques, the estimated probability was 0.001 (1/945, see Nei 1987 p. 290).

A further measure of agreement between both approaches was the significant correlation (Mantel test, $\mathrm{P}=0.0028$ after 10,000 runs) disclosed between Mahalanobis and Jaccard's distances, which was illustrated here by an exponential relationship (Fig. 2).

\section{DISCUSSION}

In our material composed of male specimens, three taxonomic groups are located on different continents, (i) the OW Phlebotomus and Spelaeophlebotomus, (ii) the Australasian OW Australophlebotomus and (iii) the remaining NW taxa. As vicariant products after fragmentation and resulting drift of Gondwanan plates (Lewis et al.
1977), these groups should have important geological times of divergence between them. For such distant taxa, electrophoresis of isoenzymes is usually not recommended (Thorpe \& Solé-Cava 1994), while discriminant analysis on continuous characters, which was used here as an exploratory "phylogenetic" tool (Sorensen \& Footit 1992, Sorensen 1992), remains controversial (Crespi 1992).

Neither proteic nor metric trees respected geography (Fig. 1); they were, however, very similar between them, and this congruence was hardly compatible with chance alone. Cladistic trees based on adult morphology showed similar patterns as ours regarding the external positions of Warileya (Rispail 1990, Galati 1992) and Spelaeophlebotomus (Rispail 1990, Rispail \& Leger 1998a), but disagreed regarding the respective positions of Brumptomyia

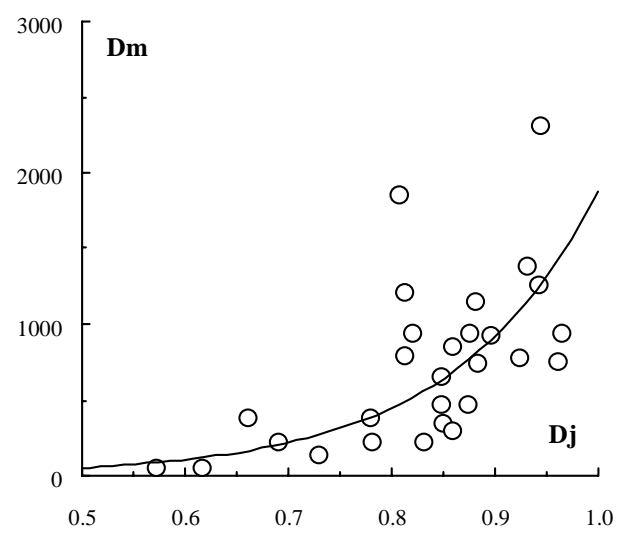

Fig. 2: plotting of Mahalanobis (Dm, vertical axis, metric data) against Jaccard $(\mathrm{Dj}$, horizontal axis, isoenzyme data) distances, showing the positive and significant correlation between them $(\mathrm{P}=0.0028$ after Mantel test, 10,000 runs). The curved line represents the exponential relationship between distances (coefficient of determination was 0.62 ). 
and Psychodopygus, both of which are closer to Lutzomyia than to Phlebotomus. Note, however, that between Lutzomyia (NW) and Phlebotomus (OW), Rispail (1990) did not produce distances significantly higher than zero.

Three salient features were shared by electrophoretic and metric data, (i) a high degree of divergence of either Spelaeophlebotomus (OW) or Warileya $(\mathrm{NW})$ with other taxa, (ii) a slightly lower degree of divergence of Australophlebotomus (Australasian region) with South America, relative to Africa, and (iii) the pairing of Phlebotomus (OW) with Lutzomyia (NW), closer together than to any other genera or subgenera with which they were expected to show more affinities.

The pairing of the OW subgenus Spelaeophlebotomus with the NW genus Warileya after isoenzyme analysis in a separate, external group (Fig. 1) could be supported by the presence in these two taxa of some plesiomorphic structures recognized in fossil Phlebotomites species (120 MYA), such as rounded wings, a complete inter-ocular suture, legs ratios, as well as the unusual feature of rods near the sperm pump (Lewis 1982). The similarities of these taxa with fossil records of 120 MYA (Lewis 1982), and their external positions on either phenetic (this paper) or cladistic trees (Rispail 1990, Galati 1992), lend support to the idea that they existed in Gondwana before continental fragmentation, and that their populations would have been subjected to division as the continental plates began to separate. According to this hypothesis, they could be assembled within the same separate, sister taxon.

The subgenus Australophlebotomus is restricted to the Australasian region. It was classified by Lewis and Dyce (1982) as a subgenus of Phlebotomus, but our study indicated relatively more affinities of Australophlebotomus with South American than with Afrotropical species (Fig. 1). There were fewer electrophoretic differences with the NW genus Lutzomyia (Jaccard 0.81, Table III below diagonal) and related subgenera (0.81-0.82) than with Phlebotomus (0.85) or Spelaeophlebotomus (0.94). Remarkably, there was a very low metric distance with the genus Warileya (Mahalanobis 293, Table III above diagonal), which parallels the observation of primitive characters, as those described for Warileya, in some Australophlebotomus species (Lewis 1982, Lewis \& Dyce 1982). The relatively lower divergence between Australophlebotomus and South American taxa could be attributed to either convergence or common ancestry. For other insects, morphological similarities between Australasian and South American taxa were related to possible exchanges during Eocene and Oligocene (55-25 MYA) (Moore 1978,
Parsons 1996). Lewis and Dyce (1982) suggested a Southern origin for Australophlebotomus, and regretted the absence of available data about the Chilean fauna. For this reason we included in our material the Lutzomyia subgenus Oligodontomyia restricted to the south-western parts of South America, including Chile (Galati 1995). However, our data provided no clear evidence of close similarity between Oligodontomyia and Australophlebotomus (Jaccard 0.82/Mahalanobis 944, see Table III).

The close proximity of Phlebotomus and Lutzomyia accords with their lack of relevant morphological differences (see Abonnenc \& Leger 1976). According to Ashford (1991), these two genera were defined on the unique criterion of geography. Partial ribosomal sequences comparisons showed that some species of Phlebotomus could indeed cluster with some Lutzomyia species (Depaquit et al. 1998). Coincidentally or not, they are the sole genera containing Leishmania vectors. Our measurements of proteic and metric divergence showed that they were closer together than they are to their corresponding subgenera (Spelaeophlebotomus, Australophlebotomus, and Oligodontomyia, Psychodopygus, respectively). It is worth noting that this unexpected proximity was predicted by the hypothesis of a Neotropical origin of the genus Leishmania (Noyes 1998).

How far our phenetic approach contains relevant phylogenetic information is however a matter of chance. Provided that the rate of gene substitution does not vary greatly among evolutionary lineages, the UPGMA tree-making method based on electrophoretic data usually contains reliable phylogenetic information (Nei 1987 p. 311, SoleCava et al. 1994). On the other hand, since discriminant analysis of metric data focuses upon "unshared" variation (Pimentel 1992), which may be considered apomorphic variation (Sorensen \& Foottit 1992), it also could portray phylogenetic relationships (Sorensen 1992). In this application, discriminant analysis is poorly affected by nonnormality and heteroscedasticity, unless the sample sizes are strongly unequal (Pimentel 1992). Our data regarding OW taxa were in agreement with the cladistic approach proposed by Rispail and Leger (1998a). However, the pairing of Phlebotomus and Lutzomyia should be regarded with caution, since a phenetic approach could be seriously invalidated by homoplasy, convergence, or by strongly unequal evolutionary rates. This prevented us from proposing a new classification to replace the current one. We believe that to help answer these questions, true cladistical methods should be used (Rispail \& Leger 1998a,b), based on relevant and practicable outgroups. In this regard, our data, as well as previous ones (Rispail 1990, Galati 1992), 
suggest that Warileya and/or Spelaeophlebotomus could be interesting candidates.

There is no doubt that DNA sequencing should provide more accurate estimations of genetic divergences among main groups of sand flies, however such data are presently lacking. Besides, isoenzyme electrophoresis techniques suffer from practical constraints such as accessibility to frozen material, which makes it difficult to assemble specimens from different continents. Also, it is important to gather more information on various representatives of the main sand fly taxa, including the large genus Sergentomyia which we did not study. Thus, morphologic and morphometric studies on adults should be further explored, and could be also improved by the use of larval characters (Vattier-Bernard 1971, Parsons 1996). Other candidate characters, such as the spermatozoa (Dallai et al. 1984) and the chromosomal structures (White \& Killick-Kendrick 1976), should be considered, along with molecular data, to provide a more complete analysis (Rangel et al. 1996).

\section{ACKNOWLEDGMENTS}

To Prof. JA Rioux, Dr P Rispail (University of Montpellier I), Mr J Mouchet (ORSTOM Paris), Prof. De Muyzon (MNHN Paris) and Prof. MD Bargues (University of Valencia) for revising this manuscript. To Prof. JP Dedet and Dr E Guilvard for generously providing specimens of $P$. papatasi.

\section{REFERENCES}

Abonnenc E, Leger N 1976. Sur une classification rationnelle des Diptères Phlebotomidae. Cah ORSTOM., sér. Entomol Méd Parasitol 14: 69-78.

Ashford RW 1991. A new morphological character to distinguish Sergentomyia and Phlebotomus, p. 7983. In M Mardi, Proc. 1st Intl Symposium on Phlebotomine Sandflies, Rome, Vol. 33 (Suppl. 1).

Chavez T, Moreno J, Dujardin JP 1999. Isoenzyme electrophoresis of Rhodnius species: a phenetic approach to relationships within the genus. Ann Trop Med Parasitol 93: 299-307.

Crespi BJ 1992. Natural selection and morphometrics, p. 55-64. In RG Foottit \& JT Sorensen (eds), Ordination in the Study of Morphology, Evolution and Systematics of Insects: Applications and Quantitative Genetic Rationales, Elsevier, New York.

Dallai R, Baccetti B, Macceni M, Sabatinelli G 1984. The spermatozoan of three species of Phlebotomus (Phlebotominae) and the acrosomal evolution in Nematoceran Dipterans. Intl Insect Morphol Embryol 13: 1-10.

Depaquit J, Perrotey S, Lecointre G, Tillier A, Tillier S, Ferte H, Kaltenbach M, Leger N 1998. Molecular systematics of Phlebotominae: a pilot study. Paraphyly of the genus Phlebotomus. CR Acad Sci Paris Life Sciences 321 : 849-855.

Dos Reis SF, Pessoa LM, Strauss RE 1990. Application of size-free canonical discriminant analysis to stud- ies of geographic differentiation. Brazil J Genet 13: 509-520.

Dujardin JP, Chavez T, Moreno JM, Machane M, Noireau F, Schofield CJ 1999. Rhodniini: the value of traditional morphometrics as a phylogenetic approach. J Med Entomol in press.

Dujardin JP, Le Pont F, Cruz M, Leon R, Tarrieu F, Guderian R, Echeverria R, Tibayrenc M 1996. Cryptic speciation in Lutzomyia (Nyssomyia) trapidoi (Fairchild \& Hertig) (Diptera: Psychodidae) detected by Multilocus Enzyme Electrophoresis. Amer J Trop Med Hyg 54: 42-45.

Forattini OP 1973. Entomologia Médica. Psychodidae. Phlebotominae. Leismanioses. Bartonelose, Vol 4, Edgar Blücher Ltda., São Paulo.

Galati EAB 1992. Sistemática dos Phlebotominae (Diptera, Psychodidae) das Américas. Thesis, São Paulo, 275 pp.

Galati EAB 1995. Phylogenetic systematics of Phlebotominae (Diptera: Psychodidae) with emphasis on American groups. Bol Dir Malariol Saneam Amb 35: 133-142.

Hennig W 1972. Insektenfossilien aus der unteren Kreide. IV. Psychodidae (Phlebotominae). Stutt Beitr Naturk 241: 1-69.

Jackson DA, Somers KM, Harvey HH 1989. Similarity coefficients: measures of co-occurrence and association or simply measures of occurrence? The Amer Natur 133: 436-452.

Lane RP 1986. Recent advances in the systematics of phlebotomine sandflies. Insect Sci Applic: 225-230.

Lane RP 1993. Sandflies (Phlebotominae), p. 78-113. In RP Lane \& RW Crosskey (eds), Medical Insects and Arachnids, Chapman \& Hall, London, 723 pp.

Lewis DJ 1982. A taxonomic review of the genus Phlebotomus (Diptera: Psychodidae). Bull Br Mus Nat Hist (Entomol) 45: 121-209.

Lewis DJ, Dyce AL 1982. The subgenus Australophlebotomus Theodor of Phlebotomus Rondani and Berté (Diptera: Psychodidae). J Aust Entomol Soc 21: 37-54.

Lewis DJ, Young DG, Fairchild GB, Minter DM 1977. Proposals for a stable classification of phlebotomine sandflies. Syst Entomol 2: 319-332.

Mahalanobis PC 1936. On the generalized distance in statistics. Proc Natl Inst Sci India 2: 49-55.

Moore BP 1978. A new Australian stag beetle (Coleoptera: Lucanidae) with Neotropical affinities. $J$ Aust Entomol Soc 17: 99-103.

Nei M 1987. Molecular Evolutionary Genetics, Columbia University Press, New York, 512 pp.

Noyes H 1998. Implications of Neotropical origin of the Genus Leishmania. Mem Inst Oswaldo Cruz 93: 657661.

Parsons MJ 1996. Gondwana evolution of the troidine swallowtails (Lepidoptera: Papilionidae): cladistic reappraisals using mainly immature stage characters, with focus on the birdwings ornithoptera Boisduval. Bull Kitakyushu Mus Nat Hist 15: 43-118.

Pimentel RA 1992. An introduction to ordination, principal components analysis and discriminant analysis, p. 11-28. In RG Foottit \& JT Sorensen (eds), 
Ordination in the Study of Morphology, Evolution and Systematics of Insects: Applications and Quantitative Genetic Rationales, Elsevier, New York.

Rangel EF, Lainson R, Souza AA, Ready P, Azevedo ACR 1996. Variation between geographical populations of Lutzomyia (Nyssomyia) whitmani (Antunes \& Coutinho, 1939) sensu lato (Diptera: Psychodidae: Phlebotominae) in Brazil. Mem Inst Oswaldo Cruz 91: 43-50.

Ready PD, Fraiha H, Lainson R, Shaw J 1980. Psychodopygus as a genus: reasons for a flexible classification of the phlebotomine sand flies (Diptera: Psychodidae). J Med Entomol 17: 75-88.

Richardson BJ, Baverstock PR, Adams SM 1986. Allozyme electrophoresis: a Handbook for Animal Systematics and Population Studies, Academic Press, Australia, Orlando, Florida, 409 pp.

Rispail P 1990. Approche Phénétique et Cladistique du Genre Phlebotomus Rondani \& Berté, 1840 (Diptera: Psychodidae). Apport des Caractères Morphologiques Imaginaux, PhD Thesis, Montpellier.

Rispail P, Léger N 1998a. Numerical taxonomy of Old World Phlebotominae (Diptera: Psychodidae). 1. Considerations of morphological characters in the genus Phlebotomus Rondani \& Berté 1840. Mem Inst Oswaldo Cruz 93: 773-785.

Rispail P, Léger N 1998b. Numerical taxonomy of Old World Phlebotominae (Diptera: Psychodidae). 2. Restatement of classification upon subgeneric morphological characters. Mem Inst Oswaldo Cruz, 93: 787-793.

Simon C 1992. Discriminant analysis of year classes of periodical cicada based on wing morphometric data enhanced by molecular information, p. 309-323. In RG Foottit \& JT Sorensen (eds), Ordination in the Study of Morphology, Evolution and Systematics of Insects: Applications and Quantitative Genetic Rationales, Elsevier, New York.

Solé-Cava AM, Russo CAM, Araujo ME, Thorpe JP
1994. Cladistic and phenetic allozyme data for nine species of sea anemones of the family Actiniidae (Cnidaria: Anthozoa). Biol J Linnean Soc 52: 225239.

Sorensen JT 1992. The use of discriminant function analysis for estimation of phylogeny: partitioning, perspective and problems, p. 65-93. In RG Foottit \& JT Sorensen (eds), Ordination in the Study of Morphology, Evolution and Systematics of Insects: Applications and Quantitative Genetic Rationales, Elsevier, New York.

Sorensen JT, Foottit RG 1992. The evolutionary quantitative genetic rationales for the use of ordination analyses in systematics: phylogenetic implications, p. 29-54. In RG Foottit \& JT Sorensen (eds), Ordination in the Study of Morphology, Evolution and Systematics of Insects: Applications and Quantitative Genetic Rationales, Elsevier, New York.

Thorpe JP, Solé-Cava AM 1994. The use of allozyme electrophoresis in invertebrate systematics. Zoologica scripta 23: 3-18.

Vattier-Bernard G 1971. Etude morphologique et biologique des phlébotomes cavernicoles du CongoBrazzaville. Annal Spél 26: 149-171.

White GB, Killick-Kendrick R 1976. Polytene chromosomes of the sandfly Lutzomyia longipalpis and the cytogenetics of Psychodidae in relation to other Diptera. J Entomol A 50: 187-196.

Wilks SS 1932. Certain generalizations in the analysis of variance. Biometrika 24: 471.

Young DG, Lawyer PG 1987. New World vectors of the leishmaniases, p. 29-71. In Kerry F Harris, Current Topics in Vector Research, Vol. 4, Springer-Verlag, New York.

Young DG, Duncan MA 1994. Guide to the Identification and Geographic Distribution of Lutzomyia Sand Flies in Mexico, the West Indies, Central and South America (Diptera: Psychodidae), Mem Amer Inst Entomol 54, Associate Publishers, Gainesville, 881 pp. 